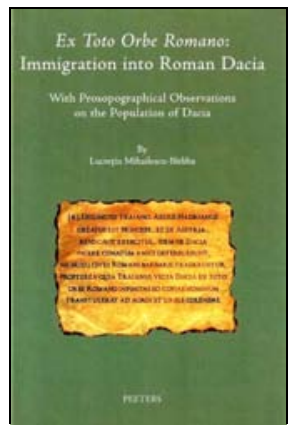

\title{
Leszek Mrozewicz
}

(Gniezno)

\section{OBCY W DACJI}

Lucreţiu Mihailescu-Bîrliba, Ex toto orbe Romano: Immigration into Roman Dacia. With Prosopographical Observations on the Population of Dacia, Peeters, Colloquia Antiqua 5, Leuven-Paris-Walpole 2011, XIII +166 s.

Mimo że od ukazania się książki mija właśnie pięć lat, z dwóch względów warto ją odnotować. Po pierwsze porusza ona problem ważny, ciągle w nauce dyskutowany, a dotyczący migracji $\mathrm{w}$ świecie rzymskim. W tym wypadku chodzi oczywiście o prowincję Dację (dzisiaj w granicach Rumunii) i intensywność jej zasiedlenia przez kolonistów ex toto orbe Romano. Zawarty w „Brewiarium” Eutropiusza odnośny przekaz (VIII 6: Traianus victa Dacia ex toto orbe Romano infinitas eo copias hominum transtulerat ad agros et urbes colendas. Dacia enim diuturno bello Decibali viris fuerat exhausta) stał się podstawą do rozwinięcia tezy o całkowitej depopulacji Dacji w następstwie podboju rzymskiego i w efekcie konieczności jej „zapełnienia” przybyszami z różnych części Imperium Romanum. Tym tłumaczy się też jej całkowicie łaciński charakter, pełną romanizację. Drugi powód to metoda zaprezentowana przez L. Mihailescu-Bîrlibę. Podstawę jego książki stanowią, co przy pracach o charakterze onomastyczno-prozopograficznym nie dziwi, rozbudowane zestawienia (tabele) z imionami własnymi wszystkich znanych mieszkańców Dacji rzymskiej. Zajmują one aż 120 stron (39-159), podczas gdy rozważania (czyli „komentarz” do tabel) to zaledwie 38 stron (1-38). Te ostatnie zawierają Wstęp i Zakończenie oraz cztery rozdziały, siłą rzeczy mikroskopijne: 1. Pochodzenie elit miejskich w Dacji rzymskiej (z podziałem na trzy podrozdziały: pierwszy o dekurionach, urzędnikach, flaminach i pontyfikach oraz ich rodzinach, drugi o członkach elit mniejszych miast, trzeci o augustalach i ich rodzinach); 2. Pochodzenie ludności z regionów górniczych Dacji (w świetle danych epigraficznych i archeologicznych); 3. Pochodzenie ludności średnich i niskich warstw społecznych Dacji (także w świetle danych epigraficznych i archeologicznych); 4. Ludność tubylcza w Dacji rzymskiej. 
Problemem istotnym są przede wszystkim autochtoni (tubylcy). Dobrze poświadczane osadnictwo rzymskie oraz przytoczone świadectwo Eutropiusza stały się podstawą tezy, długi czas dominującej w nauce, o całkowitej eksterminacji ludności dackiej. Autor wskazuje jednak na liczne świadectwa archeologiczne, które dowodzą przetrwania tubylców, oczywiście w środowisku wiejskim. Nie zostawili po sobie śladów pisanych (inskrypcji), ale danych materialnych jest aż nadto. Teza autora sprowadza się do stwierdzenia, że pogląd o całkowitym wytępieniu/wypędzeniu ludności dackiej $\mathrm{w}$ trakcie wojen i po jest przesadzony; jeszcze przed podbojem rzymskim zaludnienie Dacji było bardzo niskie.

Depopulacja, jako następstwo wojen dackich, miała miejsce, lecz nie $\mathrm{w}$ wymiarze katastrofalnym (...); zniszczone zostały elity, ale jestem przekonany, że masowa kolonizacja miała na celu zapełnienie luki demograficznej, która istniała już przed wojnami (s. 35).

Dowodem przetrwania mieszkańców Dacji jest chociażby fakt regularnego i konsekwentnego rekrutowania młodych Daków do armii rzymskiej.

Dacia was not heavily populated even before the Roman conquest. We cannot explain this by the extermination of the Dacians, but the low population density of the province can explain the massive colonization. (...) both the epigraphic and archaeological evidence suggest and support this conclusion (s. 38).

Warto wskazać, że już przed 40 laty podobne stanowisko, to jest kwestionowanie przesadzonej skali wyniszczenia ludności Dacji w trakcie i tuż po podboju, reprezentował Jan Trynkowski (Demograficzne następstwa podboju Dacji przez Rzym, [w:] M. Jaczynowska, J. Wolski (red.), Prowincje rzymskie i ich znaczenie w ramach Imperium, Warszawa 1976, s. 135-146). Polskiemu badaczowi obcy był co prawda pogląd o niskim stopniu zaludnienia Dacji przed wojnami z Rzymem, ale wskazał wyraźnie na jego konsekwencje, po części zbieżne z poglądami L. Mihailescu-Bîrliby, a po części znacznie w stosunku do nich pogłębione. Podkreślał też znaczenie materialnych świadectw, wówczas znanych w o wiele mniejszym zakresie niż obecnie, koegzystencji ludności miejscowej z nowymi mieszkańcami prowincji. To zapewne bariera językowa spowodowała, że tekst Jana Trynkowskiego, któremu brakuje chociażby obcojęzycznego streszczenia, nie znalazł się w optyce rumuńskiego badacza.

Zawarte w rozdziałach 1-3 syntetyczne spostrzeżenia autora co do pochodzenia mieszkańców prowincji są odbiciem stanu naszej wiedzy w tym zakresie. Nie są to oryginalne ustalenia autora; czasami jego stwierdzenia trącają banalnością: "One thing is certain: most of the urban elite members were foreigners" (s. 11). 
Niemniej zaprezentowane synoptyczne spojrzenie ma swoją wartość, pozwala bowiem całościowo spoglądać na procesy migracyjne Dacji, co jest ważne zwłaszcza w konfrontacji z innymi obszarami Imperium Rzymskiego. Wykreśliłbym jednak podtytuł pracy („with prosopographical observations”). Praca nie ma nic wspólnego z prozopografią; ta ostatnia zajmuje się badaniem karier urzędniczych czy wojskowych, czego w książce nie ma ani śladu. Wzmianka, że ktoś był dekurionem, urzędnikiem etc., a po nim godności te przejął syn lub ktoś z rodziny, nie jest jeszcze badaniem prozopograficznym. Walorem niewątpliwym książki jest polemiczne podejście autora do ustaleń wielu badaczy. Ale i tu pozostaje niedosyt, ponieważ polemika ta, ze względu na objętość pracy, nie jest rozwijana, jedynie sygnalizowana. Ogromnie rozbudowane tabele zawierają, jak można sądzić, kompletne zestawienie mieszkańców Dacji rzymskiej. Niewątpliwie jest to materiał pożyteczny, już przez sam fakt zebrania tych danych w jednym miejscu, z podziałem na określone kategorie. Nie miejmy jednak złudzeń: znajdziemy je, wprawdzie rozproszone, w indeksach do każdej książki, zwłaszcza wydań źródeł. 